\title{
Association of complement receptor type-I (CD35) gene polymorphism with $P$. falciparum malarial infection in Vindhyan region of Madhya Pradesh, India
}

\begin{abstract}
Malaria is a chronic disease having large prevalence in tropical and subtropical countries. CD35 protein density on RBCs determines susceptibility to $P$. falciparum infection. In our population, complement receptor Type-1 (CD35) gene polymorphism determine the density of $\mathrm{CD} 35$ protein on RBCs. As we know, CD35 protein is an adhesion protein for $P$. falciparum and high density confer chances to infection. Polymorphism of CR1 (CD35) gene, SNP Intron 27 (T520C) in our population reveals three genotypes HH, HL and LL. Genotype HL ( $\left.\mathrm{P}=0.0298^{*}\right)$ frequent distributed in population and showing association between case and control. In our population LL genotype have protective effect for $P$. falciparum infection whereas $\mathrm{HH}$, and $\mathrm{HL}$ genotype confer high density of CD35 protein on RBCs surface. The frequency of $\mathrm{H}$ allele (in case $=65.47 \%$, control $=55.38 \%$ ) is high in comparison to $\mathrm{L}$ alleles (in case $=34.52 \%$, control $=44.61 \%$ ). Frequency of $\mathrm{H}$ and $\mathrm{L}$ allele $\left(\mathrm{P}=0.0241^{*}\right)$ significantly associated but not carriage rate $(\mathrm{P}=0.2127)$ between case and control population. Elevated TNF- $\alpha$ level in blood serum reveals quantity of infection level and having strong association $\left(\mathrm{P}<0.0001^{* * *}\right)$ with P. falciparum malarial infection.
\end{abstract}

Volume I Issue 2 - 2017

\author{
Rishabh Dev Saket,' Pallavi Indurkar, ${ }^{2}$ Ugam \\ Kumari Chauhan' \\ 'Department of Centre for Biotechnology Studies,A.P.S. \\ University, India \\ Department of Medicine, Shyam Shah Medical College, India
}

Correspondence: Rishabh Dev Saket, Department of Centre for Biotechnology Studies, A.P.S. University, India, Email rdev47@gmail.com

Received: May II, 2017 | Published: June 07, 2017

Keywords: P. falciparum malaria, CR1, CD35, intron 27, TNF- $\alpha$

\section{Introduction}

The malaria is still very dangerous in the world. The World Health Organization (WHO) gave report in 2015, indicated that approximately 3.2 billion people nearly half of the world's population were at risk of malaria. Most malaria cases and deaths occur in sub-Saharan Africa. However, Asia, Latin America, and, to a lesser extent, the Middle East, are also at risk. In 2015, 97 countries and territories had ongoing malaria transmission. Between 2000 and 2015, malaria incidence among populations at risk (the rate of new cases) fell by $37 \%$ globally. In that same period, malaria death rates among populations at risk fell by $60 \%$ globally among all age groups, and by $65 \%$ among children under 5 year. ${ }^{1}$

The World Health Organization (WHO) estimated 225 million malaria cases worldwide with 781,000 deaths due to Plasmodium infection per year. Four types of Plasmodium species (P. falciparum, $P$. vivax, $P$. malariae, and $P$. ovale) are responsible for almost all human infections. Plasmodium falciparum malaria is responsible for more than one million deaths that occur each year from malaria infection in Africa. Most of these deaths occur as a result of complications such as severe malaria associated anaemia (SMA) and cerebral malaria (CM) or coma. ${ }^{2}$ Compliment Receptor 1 (CR1), a protein on RBC cells that having role in immune complex clearance. It's also known as $\mathrm{C} 3 \mathrm{~b} /$ $\mathrm{C} 4 \mathrm{~b}$ receptor or $\mathrm{CD} 35$. In humans this protein is encoded by $\mathrm{CR} 1$ gene is located at on the long arm of chromosome 1 at band 32(1q32) and lies within a complex of immune regulatory genes. The Compliment Receptor 1 (CR1) gene polymorphism conform density of CD35 on RBC cells. The human CR1 binds to a major malarial adhesin, the P. falciparum erythrocyte membrane protein-one (PfEMP-1). High density of CR1 on erythrocyte indicates high risk of falciparum..$^{3-6}$

CR1 is an immune-regulatory protein found on the surface of erythrocytes and most leukocytes, and its functions include key complement regulation of complement activation and clearance of immune complexes. Furthermore, increasing evidences from several studies suggest that CR1 plays a critical role in the pathogenesis of Plasmodium falciparum (P. falciparum) malaria. ${ }^{7,8}$

The human complement receptor 1 (CR1, $\mathrm{C} 3 \mathrm{~b} / \mathrm{C} 4 \mathrm{~b}$ receptor, $\mathrm{CD} 35)$ on erythrocytes is a membrane protein which plays an important role in immune clearance by transporting immune complexes (ICs) from peripheral blood to macrophages in liver and spleen. The rate of clearance of immune complexes from the circulation is directly related to the number of CR1 molecules expressed on erythrocytes (CR1/Eratio). Erythrocytes from different healthy individuals may show up to 10 -fold variation in the number of CR1 molecules per cell which may vary in range of 50-1,200 molecules per cell. CR1 levels have been suggested to be genetically determined, by an autosomal codominant biallelic system. Several single nucleotide polymorphisms have been found in the CR1 gene, and at least three polymorphisms of CR1 gene are related to erythrocyte surface density of CR1 molecules, which in turn are related to the rate of immune complex clearance from the circulation. The most widely studied three single nucleotide polymorphisms of CR1 gene are: A3650G (His1208Arg), intron 27 HindIII (T520C), and Pro1827Arg. Moreover, these three polymorphisms have been reported to be in strong linkage disequilibrium. ${ }^{5}$ In many reports, CR1 Intron 27 HindIII polymorphism has been suggested to result in high $(\mathrm{H})$ and low $(\mathrm{L})$ $\mathrm{CR} 1$ expression in the presence of $\mathrm{T}$ and $\mathrm{C}$ allele respectively. ${ }^{9-10}$

\section{Materials and methods}

\section{Study population}

The study population consisted of 240 unrelated subjects comprising of 110 plasmodium falciperum infected patients and 130 ethnically matched controls of central Indian population were included 
in this study. Cases included consecutive patients who attended the Department of Medicine, Shyam Shah Medical College and Sanjay Gandhi Memorial Hospital, Rewa, Ayurveda Medical College, Rewa, Ranbaxy pathology Regional collection centre Rewa, District hospital Satna, Shahdol, Sidhi. P. falciperum malaria was diagnosed in accordance with World Health Organization (WHO Expert committee 2003) criteria.

\section{Anthropometric and biochemical measurements}

Anthropometry measurements: Height and Weight were measured in light clothes and without shoes in standing position as per standard guidelines. Body Mass Index (BMI) was calculated as weight in kilograms divided by height in meters squared. Waist circumference was measured in standing position midway between iliac crest and lower costal margin and hip circumference was measured at its maximum waist to hip ratio (WHR) was calculated using waist and hip circumferences. Systolic and diastolic blood pressures were measured twice in the right arm in sitting position after resting for at least 5 minute using a standard sphygmomanometer and the average of the two reading was used.

\section{Blood collection and plasma/serum separation}

Venous blood samples were obtained from the subjects after 12hours of overnight fasting in vacutainers with and without appropriate anti-coagulants. Immediately, plasma and serum from the respective vacutainers were separated by centrifuging the tubes at 1000 rpm for $10 \mathrm{~min}$. at $4^{\circ} \mathrm{C}$.

\section{Biochemical analysis}

Biochemical parameters related to $P$. falciparum infection is elevated level of TNF- $\alpha$ cytokine in blood serum. The detection of serum level through human TNF- $\alpha$ ELISA kit (Diaclone, cat. no. 950090096).

\section{Slide preparation and confirmatory test for $P$. falciperum malaria}

Confirmatory test for P. falciperum Malaria by using Malaria Ag P.f/P.v kit (Bio Standard Diagnostic Pvt. Lmt.) then prepare slide to identify roset formation and distinguishing the healthy and infected RBCs.

\section{DNA isolation and quantification}

Genomic DNA was extracted from whole blood by the modification of salting out procedure described by Miller and coworkers. ${ }^{11}$ The isolated genomic DNAs were then tested for purity by measuring their absorbance values at $230 \mathrm{~nm}, 260 \mathrm{~nm}, 280 \mathrm{~nm}$ and $300 \mathrm{~nm}$ using nanodrop (Systronic, India). A DNA preparation was considered to be good if it had A 260nm/A 280nm ratio as approximately 1.8 and A $300 \mathrm{~nm}$ was 0.1 or lesser. Gel electrophoresis of the genomic DNAs was carried out for qualitative estimation of samples prepared. A good DNA preparation appears as single band. A horizontal agarose slab gel electrophoresis apparatus (Bangalore Genei, Bangalore, India) was used.

\section{Detection of intron-27 (T520C); single nucleotide polymorphism via PCR-RFLP}

The $520 \mathrm{C}$ genetic variant of CR1 is associated with the reduced expression of CR1 on erythrocytes through an unknown mechanism ${ }^{12,13}$ and is therefore described as the L allele, whereas the wild-type variant,
520T, is described as the $\mathrm{H}$ allele. The homozygous 520T/520T genotype $(\mathrm{H} / \mathrm{H})$ is associated with high-level CR1 expression. The homozygous $520 \mathrm{C} / 520 \mathrm{C}$ genotype $(\mathrm{L} / \mathrm{L})$ is associated with low-level $\mathrm{CR} 1$ expression, and the heterozygous $520 \mathrm{~T} / 520 \mathrm{C}$ genotype $(\mathrm{H} / \mathrm{L})$ is associated with moderate-level expression due to the co dominant $\mathrm{H}$ and $\mathrm{L}$ alleles.

\section{Primer sequences}

The oligonucleotides sequences (primers) were designed for SNP Intron 27 (T520C), rs no. rs $11118133.6,14$

$\begin{array}{cccc}\text { Intron-27 } \quad \text { (T520C); forward } & \text { primer } & \text { - } \\ \text { 5'-CAGCAGAGCCAACTTCTGACCC-3' } & & \\ \text { Intron-27 } \quad \text { (T520C); reverse } & \text { primer } & \text { - } \\ \text { 5'-CCCTTGTAAGGCAAGTCTGG-3' } & \end{array}$

\section{PCR mix}

For each DNA sample $25 \mu 1$ of PCR reaction mixture was prepared containing $5 \mu \mathrm{l}$ template DNA (final concentration 100-200ng/ $\mu \mathrm{l}$ ), $2.5 \mu \mathrm{l}$ of $10 \mathrm{X}$ Taq polymerase buffer $(10 \mathrm{mM}$ Tris $\mathrm{HCl} \mathrm{pH} 8.8,50 \mathrm{mM}$ $\mathrm{KCl}, 1.5 \mathrm{mM} \mathrm{MgCl} 2,0.01 \%$ gelatin, $0.005 \%$ Tween- $20,0.005 \%$ NP40; final concentration 1X; (Merck), $1 \mu \mathrm{l}$ of $10 \mathrm{mM}$ dNTPs (Bangalore Genei, Bangalore, India), $1 \mu \mathrm{l}$ of $25 \mathrm{pmol} / \mu \mathrm{l}$ of forward and reverse primers, $0.2 \mu \mathrm{l}$ of $5 \mathrm{U} / \mu \mathrm{l}$ of Taq DNA polymerase (final concentration 1U; Genetics Biotech Asia Pvt. Ltd. India) and sterile water to set up the volume of reaction mixture to $25 \mu \mathrm{l}$.

\section{Thermal profile}

Thermal profile used for the amplification of desired segment of gene was as follows: Initial denaturation at $95^{\circ} \mathrm{C}$ for $2 \mathrm{~min}$ and 35 cycles of denaturation at $95^{\circ} \mathrm{C}$ for $1 \mathrm{~min}$, annealing at $54^{\circ} \mathrm{C}$ for $1 \mathrm{~min}$ and extension at $74^{\circ} \mathrm{C}$ for $1 \mathrm{~min}$, followed by final extension at $74^{\circ} \mathrm{C}$ for $10 \mathrm{~min} .{ }^{6}$ PCR products were separated on $2 \%$ agarose gel $(2 \% \mathrm{w} / \mathrm{v}$, Sigma) using a $100 \mathrm{bp}$ molecular weight (MW) marker to confirm the PCR product size of 304bp.

\section{Restriction digestion by HindIII RFLP}

The $\mathrm{T}$ to $\mathrm{C}$ transition in Intron $27 \mathrm{CR} 1$ gene when amplified by PCR was than incubated with HindIII restriction enzyme (New England Biolabs, USA). Digestion of the amplified $1800 \mathrm{bp}$ PCR product gave two fragments in PAGE of $1300 \mathrm{bp}$ and $500 \mathrm{bp}$ respectively if the product was excisable by HindIII. Depending on digestion pattern, individuals were scored as genotype LL when homozygous for presence of HindII site, genotype HH when homozygous for absence of HindII site and genotype HL in case of heterozygosity (Figure 5).

\section{Result}

Our study based on slide preparation, confirmatory test for P. falciperum Malaria, ELISA for TNF- $\alpha$ level and polymorphic screening of CR1 (CD35) gene at SNP Intron 27 (T520C) rs11118133.

\section{Slide preparation and confirmatory for P. falciperum malaria:}

After confirmation of $P$. falciperum Malaria using clinical kit, we prepared slide and stained by violet then observed in compound microscope (Magnus 2.2). Figure 1 is showing Healthy RBCs in 100x magnification whereas Figure 2 is showing Plasmodium Infected RBCs (100x magnification). 


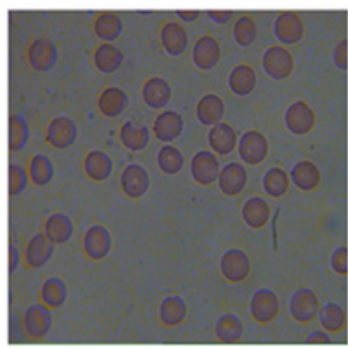

(A)

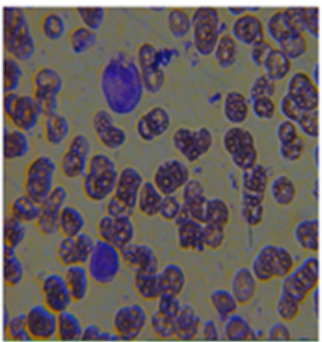

(B)
Figure I (A) 100x Healthy RBCs \& (B) 100x plasmodium infected RBCs.

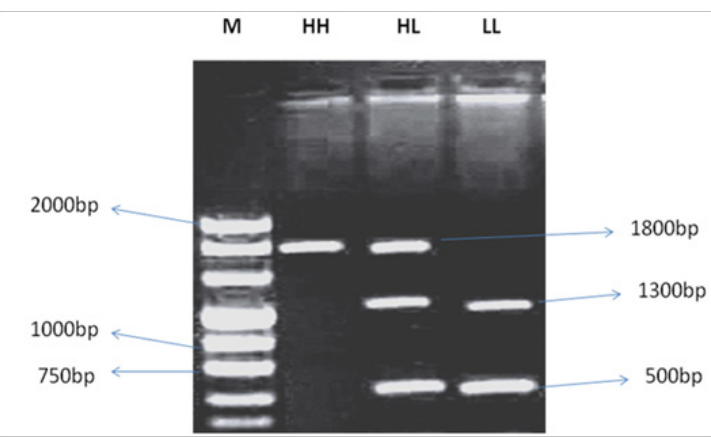

Figure 2 Restriction digestion with HindIII enzyme.

\section{Anthropometric and biochemical measurements:}

We studied on case (110) and control (130) in the respect of plasmodium infection according to anthropometric measurements like BMI (Body Mass Index), WHR (Waist Hip Ratio), some sedative habits like smoking, drinking, and TNF- $\alpha$ level in serum. During plasmodium infection, weight loss is common problem due to breakdown of RBCs thus body weight and BMI is associated with plasmodium infection whereas TNF- $\alpha$ level in serum reveals strong association with plasmodium infection. Rest of these parameters listed in Table 1, are non-significant.

Table I Comparison of anthropometric parameters of Malaria patients and controls

\begin{tabular}{|c|c|c|c|}
\hline Characteristics & Cases(I I0) & Controls(130) & P-value \\
\hline n(Men/Women) & $110(65 / 45)$ & $130(86 / 44)$ & \\
\hline Age(years) & $50.5 \pm 11.5$ & $52.0 \pm 13.2$ & $0.3533, \mathrm{~ns}$ \\
\hline Height(cm) & $158.50 \pm \mid 4.40$ & $161.20 \pm 13.00$ & $0.1284, \mathrm{~ns}$ \\
\hline \multicolumn{4}{|l|}{ Weight (Kg) } \\
\hline Women & $60.5 \pm 6.70$ & $62.4 \pm 5.50$ & $0.0166 *$ \\
\hline Men & $62 \pm 6.60$ & $64.0 \pm 6.1$ & $0.0155^{*}$ \\
\hline \multicolumn{4}{|l|}{ BMI (kg/m2) } \\
\hline Women & $24.6 \pm 8.1$ & $26.5 \pm 3.3$ & $0.0152 *$ \\
\hline Men & $26.1 \pm 7.5$ & $27.8 \pm 5.2$ & $0.040 I^{*}$ \\
\hline \multicolumn{4}{|l|}{$\begin{array}{l}\text { Waist } \\
\text { circumference } \\
(\mathrm{cm})\end{array}$} \\
\hline Women & $88.60 \pm 7.2$ & $87.45 \pm 6.5$ & $0.1949, \mathrm{~ns}$ \\
\hline
\end{tabular}

Table Continued...

\begin{tabular}{|c|c|c|c|}
\hline Characteristics & Cases(II0) & Controls(130) & P-value \\
\hline Men & $90.0 \pm 6.0$ & $89.0 \pm 8.0$ & $0.28 \mathrm{I}, \mathrm{ns}$ \\
\hline \multicolumn{4}{|l|}{$\mathrm{Hip}(\mathrm{cm})$} \\
\hline Women & $96.0 \pm 7.0$ & $96.5 \pm 4.0$ & $0.4897, \mathrm{~ns}$ \\
\hline Men & $92.0 \pm 3.0$ & $91.5 \pm 4.5$ & $0.3216, \mathrm{~ns}$ \\
\hline \multicolumn{4}{|l|}{ WHR } \\
\hline Women & $0.96 \pm 0.05$ & $0.95 \pm 0.08$ & $0.2569, \mathrm{~ns}$ \\
\hline Men & $0.98 \pm 0.08$ & $0.99 \pm 0.01$ & $0.1590, \mathrm{~ns}$ \\
\hline Cigarette smoking & $43 / 67$ & $48 / 82$ & $X^{2}=0.1190$ \\
\hline $\begin{array}{l}\text { (Smoking/ Non- } \\
\text { Smoking) }\end{array}$ & & & $(p=0 \cdot 0.7302), n s$ \\
\hline $\begin{array}{l}\text { Alcohol } \\
\text { consumption }\end{array}$ & $56 / 54$ & $53 / 77$ & $X^{2}=2.47 I$ \\
\hline $\begin{array}{l}\text { (Drinking/ Non- } \\
\text { Drinkig) }\end{array}$ & & & $(P=0.1159), n s$ \\
\hline TNF- $\alpha$ Cytokine & & & \\
\hline $\begin{array}{l}\text { Level in serum } \\
(\mathrm{pg} / \mathrm{mL})\end{array}$ & $24.7 \pm 9.52$ & $|0.2 \pm 6.4|$ & $(\mathrm{P}<0.000 \mathrm{I}) * * *$ \\
\hline
\end{tabular}

*Denotes level of significant change between case and control

\section{Detection Of genetic polymorphism in CR I (CD35) Gene:}

PCR amplification with specific primers gave 1904-bp product which was digested with HindIII enzyme (New England Biolabs, Boverly, MA) for $16 \mathrm{~h}$ at $37^{\circ} \mathrm{C}$. The wild-type genotype $(\mathrm{HH})$ was digested, whereas the mutated homozygous genotype (LL) was cut as a doublet of 1300 and 500BP. The heterozygous genotype (KQ) was represented as 3 fragments of 1800, 1300, and 500bp as depicted in Figure 2.

\section{Chi square test}

Table 2 containing Genotype, Allele frequency and carriage rate of CR1 (CD35) gene. Case -Control study in respect of Chi Square Test reveals that two type allele present in three genotype HH, HL, LL. For this statistical analysis, we used Graph Pad Prism software. In Table 2 Allele frequency and carriage rate are showing significantly associated whereas genotypic frequency showing slightly association.

Table 2 Frequency distribution and association of Genotype, allele frequency and carriage rate of CRI (CD35) polymorphism in population of Vindhyan region using chi square test

\begin{tabular}{|c|c|c|c|}
\hline $\begin{array}{l}\text { CRI(CD35) } \\
\text { gene }\end{array}$ & $\begin{array}{l}\text { Case } \\
N=\mid \text { I 0N\% }\end{array}$ & $\begin{array}{l}\text { Control } \\
N=130 N \%\end{array}$ & $\begin{array}{l}\text { chi square value } \\
\chi 2 \text { (P value) }\end{array}$ \\
\hline \multicolumn{4}{|l|}{ Genotype } \\
\hline $\mathrm{HH}$ & 4843.63 & 4534.61 & $7.028,(0.0298 *)$ \\
\hline $\mathrm{HL}$ & 5045.45 & $544 I .53$ & $D f=2$ \\
\hline LL & 1210.90 & 3123.84 & \\
\hline \multicolumn{4}{|l|}{ Allele } \\
\hline $\mathrm{H}$ & 14665.47 & I4455.38 & $5.090,(0.024 I *)$ \\
\hline L & 7734.52 & II 644.6 I & $D f=I$ \\
\hline
\end{tabular}


Table Continued....

$\begin{array}{llll}\begin{array}{lll}\text { CRI(CD35) } \\ \text { gene }\end{array} & \begin{array}{l}\text { Case } \\ \mathbf{N}=11 \text { ON\% }\end{array} & \begin{array}{l}\text { Control } \\ \mathbf{N}=130 N \%\end{array} & \begin{array}{l}\text { chi square value } \\ \chi 2\end{array} \text { (P value) }\end{array}$

$\mathrm{N}-$ Number of individuals in study group

$\%$ - Genotype allele frequency and carriage rate expressed in percentage

(* Denotes the level of significant association between case and control)

Table 3 Fisher exact test values of CRI (CD35) polymorphism

\begin{tabular}{lllll}
\hline $\begin{array}{l}\text { CRI(CD35) } \\
\text { gene }\end{array}$ & $\begin{array}{l}\text { Case } \\
\mathbf{N}=110 n \%\end{array}$ & $\begin{array}{l}\text { Control } \\
\mathbf{N}=130 n \%\end{array}$ & P value & Odds ratio \\
\hline Genotype & & & & \\
$\mathrm{HH}$ & 4843.63 & $4534.6 \mathrm{I}$ & 0.1837 & $\begin{array}{l}\text { I.462, }(0.8675 \\
\text { to } 2.465)\end{array}$ \\
$\mathrm{HL}$ & 5045.45 & 5441.53 & 0.6015 & $\begin{array}{l}1.173,(0.7025 \\
\text { to } 1.958)\end{array}$ \\
$\mathrm{LL}$ & 1210.90 & 3123.84 & $0.0110 *$ & $\begin{array}{l}0.3910,(0.1898 \\
\text { to } 0.8056)\end{array}$
\end{tabular}

Allele

\begin{tabular}{|c|c|c|c|c|}
\hline $\mathrm{H}$ & 14665.47 & I44 55.38 & \multirow[t]{2}{*}{$0.0256^{*}$} & $\begin{array}{l}1.527,(1.056 \text { to } \\
2.209)\end{array}$ \\
\hline L & 7734.52 & II 644.61 & & $\begin{array}{l}0.6547,(0.4527 \\
\text { to } 0.9468)\end{array}$ \\
\hline \multicolumn{5}{|c|}{ Carriage Rate } \\
\hline $\mathrm{H}$ & 9560.50 & 9953.80 & \multirow[t]{2}{*}{0.2287} & $\begin{array}{l}1.316,(0.8542 \\
\text { to } 2.026)\end{array}$ \\
\hline L & 6239.49 & 8546.19 & & $\begin{array}{l}0.760 I,(0.4936 \\
\text { to I.I7I) }\end{array}$ \\
\hline
\end{tabular}

$\mathrm{N}$ - Number of individuals in study group

\%- Genotype allele frequency and carriage rate expressed in percentage

(* Denotes the level of significant association between case and control)

\section{Fisher exact test}

Fisher Exact test between case and control for Genotype frequency, allele frequency and carriage rate is showing P-value and Odds ratio.

\section{Graphical representation of genotype frequency, allele frequency and carriage rate:}

In our population, HL genotype frequency was high in both case $(44.54 \%)$ and Control $(38.46 \%)$ and allele frequency of $\mathrm{H}$ allele were high in both case $(64.09 \%)$ and control $(51.63 \%)$. Thus carriage rate of $\mathrm{H}$ - allele is also high in case (63.84\%) and control (51.11\%) (Figures 3-5).

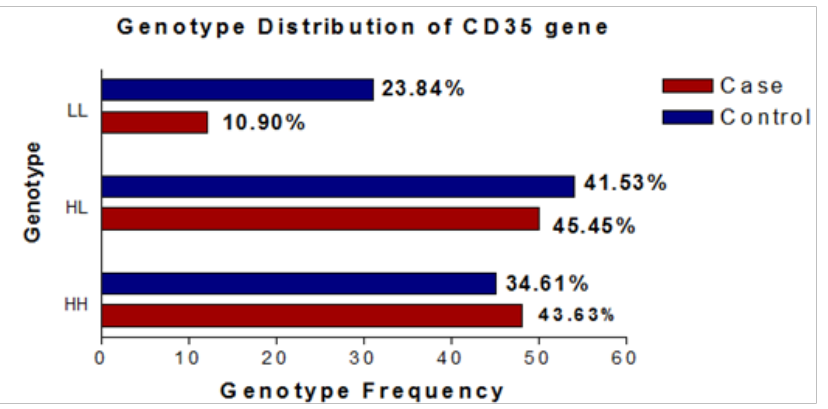

Figure 3 Genotype frequency of CRI (CD35) gene.

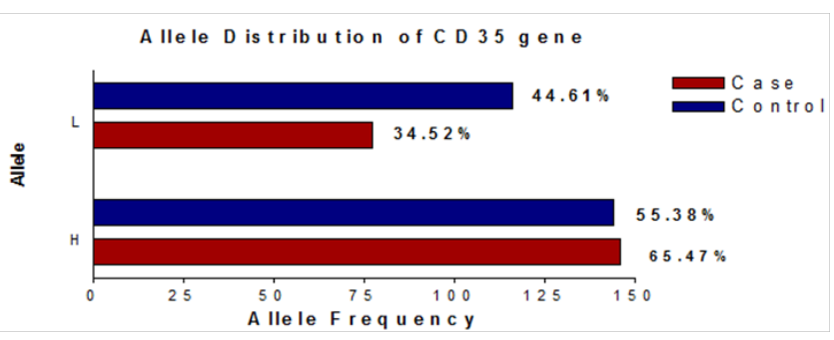

Figure 4 Allele frequency of CRI (CD35) gene.

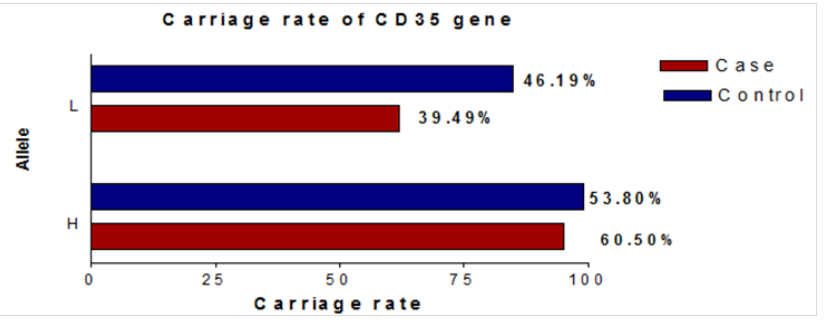

Figure 5 Carriage rate of CRI (CD35) gene.

\section{Discussion}

Malaria is a life threatening disease caused by parasites that are transmitted to people through the bites of infected female mosquitoes. Most of these deaths occur as a result of complications such as severe malaria associated anaemia (SMA) and cerebral malaria $(\mathrm{CM})$ or coma. ${ }^{15}$ Malaria is considered to be one of the strongest forces of natural selection to have influenced the human genome in recent history. Genetic disorders that diminish the severity of malaria, including sickle-cell disease and thalassemia, demonstrate that mutations causing otherwise deleterious conditions have become fixed in human populations in specific areas as a result of selective pressure related to malaria pathogenesis. ${ }^{16,17}$ In our study, we focused on polymorphism of CR1 (CD35) gene and its association with Plasmodium falciparum malaia in vindhyan region (including Rewa, Satna, Sidhi, Sahdole district) of Madhya Pradesh, India. We first prepare blood smear of malarial infected and healthy individuals (Figure 1A). Microscopic observation is showing RBCs with malarial infection (Figure 1B) then conformational testing for Plasmodium falciparum, used clinical kit.

We studied 110 case and 130 control including men and women separately. First we analyzed anthropometric and biochemical parameters (table no.1) in which anthropometric parameter BMI was significantly associated with malarial infection in men $(P=0.0401$ *) and women $(P=0.0152 *)$ that means weight loss observed during malarial infection whereas other parameters like age, height and WHR were not associated. Life style factor like Cigarette smoking and Alcohol consumption were also non significantly associated with malarial infection where as biochemical parameter, TNF- $\alpha$ Cytokine Level in serum were showing strong association $\left(\mathrm{P}<0.0001^{* * *}\right)$ with malarial infection.

In our study, we found two allele of CD35 gene. A H-allele and another L-allele. Thus three genotype HH, HL, and LL seen in vindhyan population. $\mathrm{H}$ allele having $1800 \mathrm{bp}$ whereas $\mathrm{L}$ allele spliced into $1300 \mathrm{bp}$ and $500 \mathrm{bp}$. The frequency of HL genotype were high than HH and LL genotype $\left[\chi 2\right.$ (P Value) $\left.=7.028,\left(0.0298^{*}\right)\right]$. The allele frequency of $\mathrm{H}$ were high then $\mathrm{L}\left[\chi^{2}(\mathrm{P}\right.$ Value $\left.)=5.090,\left(0.0241^{*}\right)\right]$. Carriage rate of $\mathrm{H}$ allele were also high $[\chi 2(\mathrm{P}$ Value $)=1.553,(0.2127)]$ but not significantly associated. Thus we also calculated Fisher Exact Test of population. The genotype LL is showing association between case and control $\left(\mathrm{P}=0.0110^{*}\right)$, odds ratio (0.3910). Allele fisher exact 
were $\mathrm{P}=0.0256^{*}$ is showing association but no any association in carriage rate $(\mathrm{P}=0.2287)$. Thus, $\mathrm{LL}$ genotype has protective effect for malarial infection.

Our study was polymorphism in expression level of CD35 protein on RBCs. My studies was nearly similar to study in Papua New Guinea, a malaria endemic area, Cockburn et al. found that a polymorphism that caused a reduction in the number of CR1 molecules on erythrocytes conferred protection against severe malaria. He found that the frequencies of the $\mathrm{L} / \mathrm{L}$ allelic variant were highest in population that caused low-level expression of CR1 on erythrocytes. ${ }^{18}$ But in my population $\mathrm{H}$ allele in high frequency that means $\mathrm{CR} 1$ expression is high and highly susceptible to plasmodium infection. In addition, African population, Another SNP of CR1,A4828G (R1601G), is highly prevalent in malaria endemic areas of Africa, but a study in Gambia showed that it was not associated with severe malaria. ${ }^{19}$ However, the findings of a similar study of various European populations supported the role CR1 (CD35) polymorphism in malarial infection. ${ }^{20}$ The work of A. Srivastava et al. Indian population suggests that decreased expression of complement receptor 1 (CR1) on erythrocytes confirm reduced clearance of immune complexes, conferring inter individual variation for gallbladder cancer (GBC) susceptibility. They studied role of CR1 (A3650G RsaI and Intron 27 HindIII) polymorphisms in gallstone disease and GBC in north Indian population. Genotyping was done by PCR-RFLP. They did not find any association of A3650G RsaI and Intron 27 HindIII with gallstone disease and GBC, but they stabilize polymorphism of CR1 gene (Intron 27 HindIII) and their role in immune complex clearance. ${ }^{21}$ My study is also reveal Intron 27 HindIII polymorphism in north Indian population and stabilizes an association to $P$. falciparum malarial infection.

L. Xiang et al. ${ }^{14}$ studied quantitative expression of complement receptor type 1 (CR1) on erythrocytes is regulated by two CR1 alleles $\mathrm{H}$ and $\mathrm{L}$ that differ in having genomic HindIII fragments. The HindIII RFLP were analyzed in genomic DNA of 85 Caucasians and 75 African Americans; sites encoding the other amino acid substitutions were analyzed less extensively. Two major haplotypes defined prototypic $\mathrm{H}$ and $\mathrm{L}$ alleles in both ethnic groups, suggesting that these alleles existed before the African and European populations diverged. Decreased erythrocyte CR1 expression is associated with impaired clearance of immune complexes from blood. Persistence of the $\mathrm{L}$ allele in all populations that have been analyzed may suggest protective allele to malarial infection. ${ }^{14}$ This study is similar to our study population having odds ratio below from $0.5(0.3823)$ in LL genotype.

Another role of Complement receptor-type 1 (CR1, CD35) is the immune-adherence receptor, a complement regulator, and an erythroid receptor for Plasmodium falciparum during merozoite invasion and subsequent rosette formation involving parasitized and non-infected erythrocytes. ${ }^{22}$ P.B. Tetteh-Quarcoo et al. Studied in Plasmodium falciparum infection, complement receptor-1 (CR1) on erythrocyte's surface and $\mathrm{ABO}$ blood group play important roles in formation of rosettes which are presumed to be contributory in the pathogenesis of severe malaria. Although several studies have attempted to determine the association of CR 1 polymorphisms with severe malaria, observations remain inconsistent. Therefore, a case control study and meta-analysis was performed to address this issue. Methods: Common CR1 polymorphisms (intron 27 and exon 22) and blood group were typed in 353 cases of severe malaria (SM) (97cerebral malaria (CM), 129multi-organ dysfunction (MOD), 127 non-cerebral severe malaria (NCSM)), 141 uncomplicated malaria and 100 healthy controls from an endemic region of Odisha, India. The homozygous polymorphisms of CR1 intron 27 and exon 22 (TT and GG) and alleles ( $\mathrm{T}$ and $\mathrm{G}$ ) that are associated with low expression of $\mathrm{CR} 1$ on red blood cells, conferred significant protection against CM, MOD and malaria deaths. Combined analysis showed significant association of blood group B/intron 27-AA/exon 22-AA with susceptibility to SM (CM and MOD). Meta-analysis revealed that the CR1 exon 22 low expression polymorphism is significantly associated with protection against severe malaria. The results of the present study demonstrate that common CR1 variants significantly protect against severe malaria in an endemic area. ${ }^{23}$ Our study is also showing high expression of $\mathrm{CR} 1$ on RBCs facilitate binding of plasmodium and increased level of TNF- $\alpha$ Cytokine in blood. TNF- $\alpha$ is anti-inflammatory cytokine and act as a marker to malarial infection. ${ }^{24}$ TNF- $\alpha$ level in Healthy and case population reveal strong association $(\mathrm{P}<0.0001 * * *)$ that is similar to P.B. Tetteh-Quarcoo study. In our population, frequency of $\mathrm{H}$ allele is high than $\mathrm{L}$ allele and LL genotype in low numbers have protective effect for P. falciparum infection. HH and HL allele confer, CD35 protein density is high in RBCs surface and such individuals are highly susceptible to Plasmodium falciparum malaria. Our study nearly close to A. Srivastava \& B. Mittal's studies in north Indian population.

\section{Acknowledgements}

None.

\section{Conflict of interest}

The author declares no conflict of interest.

\section{References}

1. World health organization report; 2015

2. Cavasini MT, Ribeiro WL, Kawamoto F, How prevalent is Plasmodium malariae in Rondonia, western Brazilian Amazon? Rev Soc Bras Med Trop. 2000;33(5):489-492.

3. Ahearn JM, Fearon DT. Structure and function of the complement receptors, CR1(CD35) and CR2 (CD21). Adv Immunol. 1989;46:183219.

4. Moulds JM, Thomas BJ, Doumbo O, et al. Identification of the Kna Knb polymorphism and a method for Knops genotyping. Transfusion. 2004;44(2):164-169.

5. Thomas BN, Donvito B, Cockburn I, et al. A complement receptor 1 polymorphism with high frequency in malaria endemic regions of Asia but not Africa. Genes Immun. 2005;6(1):31-36.

6. Cornillet P, Philbert F, Kazatchkine MD, et al. Genomic determination of the CR1 (CD35) density polymorphism on erythrocytes using polymerase chain reaction amplifi cation and HindIII restriction enzyme digestion. J Immunol Methods. 1991;136(2):193-197.

7. Awandare GA, Spadafora C, Moch JK, et al. Plasmodium falciparum field isolates use complement receptor 1 (CR1) as a receptor for invasion of erythrocytes. Mol Biochem Parasitol. 2011;177(1):57-60.

8. Stoute JA. Complement receptor 1 and malaria. Cell Microbiol. 2011;13(10):1441-1450.

9. Nagayasu E1, Ito M, Akaki M, et al. CR1 density polymorphism on erythrocytes of falciparum malaria patients in Thailand. Am J Trop Med Hyg. 2001;64(1-2):1-5.

10. Zorzetto M, Bombieri C, Ferrarotti I, et al. Complement receptor 1 gene polymorphisms in sarcoidosis. Am J Respir Cell Mol Biol. 2002;27(1):17-23. 
11. Miller SA, Dykes DD, Polesky HF. A simple salting out procedure for extracting DNA from human nucleated cells. Nucleic Acids Res. 1988;16(3):1215.

12. Liu D, Niu ZX. The structure, genetic polymorphisms, expression and biological functions of complement receptor type 1(CR1/CD35). Immunopharmacol Immunotoxicol. 2009;31(4):524-535.

13. Lord J, Morgan K. Complement Component (3b/4b) Receptor 1 (CR1) Genet Variants Alzheimer's Disease. 2013. p. 77-101.

14. Lianbin X, Jennifer RR, Derrick RH, et al. Quantitative Alleles of CR1 Coding Sequence Analysis and Comparison of Haplotypes in Two Ethnic Groups. J Immunol. 1999;163(9):4939-4945

15. Miller LH, Baruch DI, Marsh K, et al. The pathogenic basis of malaria. Nature. 2002;415(6872):673-679.

16. Kwiatkowski DP. How malaria has affected the human genome and what human genetics can teach us about malaria. Am J Hum Genet. 2005;77(2):171-192.

17. Williams TN, Weatherall DJ. World distribution, population genetics, and health burden of the hemoglobinopathies. Cold Spring Harb Perspect Med. 2012;2(9):a011692.

18. Cockburn IA, Mackinnon MJ, O’Donnell A, et al. A human complement receptor 1 polymorphism that reduces Plasmodium falciparum rosetting confers protection against severe malaria. Proc Natl Acad Sci U.S. A 2004;101(1):272-277.
19. Zimmerman PA, Fitness J, Moulds JM, et al. CR1 Knops blood group alleles are not associated with severe malaria in the Gambia. Genes Immun. 2003;4(5):368-373.

20. Kosoy R, Ransom M, Chen H, et al. Evidence for malaria selection of a CR1 haplotype in Sardinia. Genes Immun. 2011;12(7):582-588.

21. Srivastava A, Mittal B. Complement Receptor 1 (A3650G RsaI and Intron 27 HindIII) polymorphisms and risk of gallbladder cancer in north indian population. Scand J Immunol. 2009;70(6):614-620.

22. Panda AK, Panda M, Tripathy R, et al. Complement Receptor 1 Variants Confer Protection from Severe Malaria in Odisha, India. PLoS One. 2012;7(11):e49420.

23. Suffer N, Grau GE, Headberg K, et al. Tumour necrosis factor and sever malaria. J Infect Dis. 1991;163(1):96-101.

24. Tetteh-Quarcoo PB, Schmidt CQ, Tham WH, et al. Lack of evidence from studies of soluble protein fragments that knops blood group polymorphisms in complement receptor-type 1 are driven by Malaria. PLoS One. 2012;7(4):e34820. 